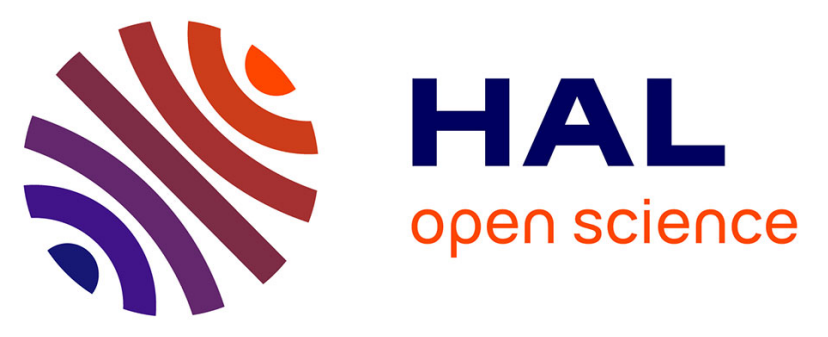

\title{
Surgical rather than endoscopic resection of early-stage colorectal cancers promotes excessive imaging surveillance
}

Martin Bordet, Jean-François Bretagne, Christine Piette, Chloé Rousseau, Thomas Grainville, Mathilde Cosson, Astrid Lièvre

\section{To cite this version:}

Martin Bordet, Jean-François Bretagne, Christine Piette, Chloé Rousseau, Thomas Grainville, et al.. Surgical rather than endoscopic resection of early-stage colorectal cancers promotes excessive imaging surveillance. Clinics and Research in Hepatology and Gastroenterology, 2021, 45 (6), pp.101735. 10.1016/j.clinre.2021.101735 . hal-03283081

\section{HAL Id: hal-03283081 https://hal.science/hal-03283081}

Submitted on 16 Jul 2021

HAL is a multi-disciplinary open access archive for the deposit and dissemination of scientific research documents, whether they are published or not. The documents may come from teaching and research institutions in France or abroad, or from public or private research centers.
L'archive ouverte pluridisciplinaire HAL, est destinée au dépôt et à la diffusion de documents scientifiques de niveau recherche, publiés ou non, émanant des établissements d'enseignement et de recherche français ou étrangers, des laboratoires publics ou privés. 


\section{SURGICAL RATHER THAN ENDOSCOPIC RESECTION OF EARLY-STAGE COLORECTAL CANCERS PROMOTES EXCESSIVE IMAGING SURVEILLANCE}

Martin Bordet, $\mathrm{MD},{ }^{1}$ Jean-François Bretagne, $\mathrm{MD}, \mathrm{PhD},{ }^{2}$ Christine Piette, $\mathrm{MD},{ }^{3}$ Chloé Rousseau, BS, ${ }^{4}$ Thomas Grainville, MD, ${ }^{1}$ Mathilde Cosson, MD, ${ }^{3}$ Astrid Lièvre, MD, $\mathrm{PhD}^{1,2,3,5}$

${ }^{1}$ Department of Gastroenterology, University Hospital, 35033 Rennes, France

${ }^{2}$ Rennes 1 University, 35000 Rennes, France

${ }^{3} \mathrm{ADECl} 35$ (Association pour le Dépistage des Cancers en Ille-et-Vilaine), 35040 Rennes, France

${ }^{4}$ Department of Biostatistics, University Hospital, 35033 Rennes, France

${ }^{5}$ COSS (Chemistry Oncogenesis Stress Signaling), UMR_S 1242, Rennes, France

Corresponding author: J.-F. Bretagne; Phone: +33 607491311;

E-mail: jf.bretagne@gmail.com

Highlights

- Little is known about the use of imaging surveillance after curative resection of earlystage colorectal cancer.

- Imaging surveillance was analyzed in a cohort of 450 patients with screening-detected stage 0 or stage 1 colorectal cancers.

- Imaging surveillance was performed for 159 (35.3\%) patients, more often for those with stage $1(66.5 \%)$ than stage $0(14.2 \%)$ tumors. 
- Factors significantly associated with surveillance in the entire cohort were the gastroenterologist assigned to the patient and surgical vs endoscopic resection.

- This study highlights the abusive and paradoxical nature of imaging surveillance in patients undergoing surgery, resulting in additional costs and potential risk to the patient.

\section{Summary}

Background and aims: Imaging surveillance after curative resection of colorectal cancer (CRC) is debated, particularly in cases of early-stage CRC. The aim of this study was to retrospectively analyze whether and how patients with screened stage 0 and stage 1 CRC were monitored by imaging.

Methods: A cohort of patients with stage 0 (intramucosal) or stage 1 (T1NO) CRC detected from 2003 to 2015 through the French national screening programme was included. All imaging findings were recorded. Statistical analyses were performed for the entire cohort $(n=450)$ and separately for the two groups (stage $0 n=268$, stage $1 n=182$ ). Factors associated with imaging surveillance, including the patient's referring gastroenterologist, were determined by logistic regression.

Results: A total of 450 patients were followed up for $6.6 \pm 3.9$ years. Imaging surveillance was performed for 159 (35.3\%), more often for those with stage 1 (66.5\%) than stage 0 (14.2\%) tumours $(p<.0001)$. Within the stage 1 group, 17 of the 47 patients $(36.2 \%)$ treated by local (endoscopic or surgical transanal) resection alone were followed up by imaging monitoring. 


\section{CLINRE-D-21-0036}

Factors significantly associated with surveillance in the entire cohort were the gastroenterologist assigned to the patient $(p<.0001)$ and surgical vs endoscopic resection $(\mathrm{OR}=39.0, \mathrm{p}<.0001)$. The histological risk of lymph node metastasis was not significantly associated with imaging monitoring for stage 1 patients. Of the 5 patients who developed distant metastasis during follow-up, one was diagnosed through imaging surveillance.

Conclusion: This study demonstrates excessive imaging surveillance for early-stage cancers. The use of surgical over endoscopic tumour resection could promote unnecessary surveillance.

Key words: early-stage colorectal cancer, endoscopic therapy, surgical treatment, colorectal cancer screening, imaging surveillance

List of abbreviations: $\mathrm{CRC}$, colorectal cancer; $\mathrm{CT}$, computed tomography; US, ultrasonography; IMC, intramucosal cancer; UICC, Union for International Cancer Control; OR, odds ratio; $\mathrm{Cl}$, confidence interval; 18-FDG PET, 18-Fluorodeoxyglucose Positron Emission Tomography 


\section{Introduction}

Despite the decrease in colorectal cancer (CRC) incidence and mortality following, in part, the roll-out of screening [1], CRC remains the second most common cause of cancer death in the US [2] and Europe [3]. Progress against CRC could be accelerated by increasing access to guideline-recommended screening and the high-quality management of screened premalignant polyps and early-stage CRCs, the proportion of which has increased following the implementation of organized screening programmes with respect to the symptomatic population [4]. It has been stated that the management of screening-detected carcinomas should not differ, stage for stage, from that required for symptomatic disease [5]. In contrast to colonoscopy surveillance after curative resection of CRCs, imaging surveillance has received little mention in the guidelines for quality assurance in screening programmes. European guidelines have considered it appropriate to perform biannual cross-sectional imaging of the abdomen for a period of 3 years for patients with high-risk pT1 cancers without completion surgery [5]. Surveillance recommendations for CRC differ from one professional society to another in terms of modalities and frequency of examinations [6]. Contrary to the American Society of Clinical Oncology [7] and the National Comprehensive Cancer Network [8], who do not consider stage I CRC for imaging surveillance after curative resection, the European Society for Medical Oncology consensus guidelines [9] on surveillance of colon cancer include stages I to III, even if the same guidelines for rectal cancer [10] are less clear. Thus, at least 2 chest/abdomen/pelvis computed tomography (CT) scans are recommended in the first 3 years [9]. When the CRC national screening programme was launched in France in 2003, the French recommendations suggested ultrasonography (US) of the liver every 3-6 months during the first three years after curative resection and annually during the next two years [11]. It is 


\section{CLINRE-D-21-0036}

stated that chest/abdomen CT scans could replace both examinations, but CT scans were considered the first-line examination in 2008 [12]. At that time, however, the latter recommendation did not specify the stages of cancer that required such monitoring, thus granting great leeway to practitioners' interpretations and opening the potential for abuse. Therefore, the aim of this study was to analyze French practitioners' adherence to imaging surveillance guidelines for screening-detected early-stage cancers, including intramucosal cancers (IMCs), which in France rank among the cancers detected in the national screening programme. 


\section{Population and methods}

\section{Study population}

This study was a retrospective analysis of the modalities and frequency of imaging surveillance during the follow-up of two cohorts of patients with IMC or T1 carcinomas diagnosed by colonoscopy following a positive fecal blood test through the French national screening programme applied in the 'Ille et Vilaine' district from 2003 to 2015. Baseline and follow-up data were prospectively and regularly collected from general practitioners, gastroenterologists, surgeons and pathologists by the ADECI 35 (Association du Dépistage des Cancers en Ille-et-Vilaine) staff. Patient and tumour characteristics in both the IMC and T1 cancer cohorts and their initial management were detailed in two recent articles $[13,14]$. According to the Union for International Cancer Control (UICC) TNM classification [15], IMC was defined as cancer cells confined to the mucosal lamina propria with no extension through the muscularis mucosae into the submucosa, and T1 was defined as a tumour invading the submucosa. According to the French recommendations [16], intraepithelial carcinomas were excluded from the study. From 2003 to 2015, the organized screening programme led to the detection of 489 early-stage CRCs, including 282 IMCs and 207 T1 CRCs. Patients with lymph node metastases on surgical specimens were excluded from the present study, which included patients with early-stage CRCs only, corresponding to and referred to in this article as stage 0 and stage 1 CRCs [15].

\section{Follow-up and imaging surveillance}

The start of follow-up was the date of cancer treatment, whether endoscopic or surgical. When follow-up data were missing from the database, information was obtained from the general practitioner, gastroenterologist, or surgeon, and the patient records were thoroughly 
reviewed when necessary by two of the authors (MB and TG). The date of the first and last follow-up visits, the date of last contact and the date of death (whether or not related to the initial disease) were recorded. The duration of follow-up was defined as the time between the initial treatment and the date of last contact. The development of local and metastatic recurrence was registered, but endoscopic surveillance is not addressed in this paper. The date, number, type, and findings of the imaging procedures, either US or chest/abdomen CT, were recorded for each patient. US and CT scan findings were analyzed separately and in a pooled manner for the same patient. Intensive surveillance was defined by at least 5 examinations per patient or examinations performed for at least 2.5 years, i.e., half of the recommended duration [12].

\section{Statistical analysis}

The main outcome was to analyze imaging surveillance in real life and to assess the factors associated with that surveillance. Quantitative variables are expressed as the means and standard deviations or medians and interquartile ranges and were compared with the t-test or the Mann-Whitney-Wilcoxon test. Qualitative variables are expressed as numbers or percentages and were compared with the $\chi^{2}$ test or Fisher's test. The factors associated with imaging and intensive surveillance were investigated using univariable logistic regression. Potential covariates $(p<.20)$ were placed into a multivariable logistic regression model that was performed using stepwise backward elimination. Odds ratios (ORs) and the corresponding 95\% confidence intervals ( $\mathrm{Cls}$ ) were used to express the association between the studied factors and imaging surveillance.

Analyses were carried out for the entire cohort of early-stage CRCs and for the stage 0 and 1 groups separately. Factors studied for univariable logistic regression in the entire cohort were those related to the patient (age, sex), the tumour (location, size), initial treatment (date, 
surgical vs endoscopic resection), cancer staging (stage 0 vs 1), and the gastroenterologist who managed the patient. For this last factor, we selected gastroenterologists who performed 15 colonoscopies or more involving one early-stage cancer, whereas those involved in fewer than 15 cases were combined together and considered one gastroenterologist. Patients treated by transanal resection were analyzed in 2 ways: one by including them in the surgery group and the other by associating them with those treated by endoscopic resection alone as a local resection procedure. In addition, the risk of lymph node metastasis was taken into account for stage 1 patients. Thus, these patients were categorized as having either a low or high risk of lymph node metastasis according to the absence or presence of at least one of the following prognostic pathological criteria as notified in the pathology report: poor differentiation, venous and lymphatic invasion, tumour budding, submucosal invasion depth $\geq 1000 \mu \mathrm{m}$ for sessile polyps or a Haggitt level of invasion $\geq 3$ for pedunculated polyps, and margin involvement with a clearance of $1 \mathrm{~mm}$ or less [17].

All analyses were performed using the statistical software programme SAS, version 9.4 (SAS Institute, Inc., Cary, North Carlina, USA). A test was interpreted as significant if $\mathrm{p}$ was less than .05 . 
CLINRE-D-21-0036

\section{Results}

Study population and follow-up

Of the cohort of 489 patients with screening-detected IMC or T1 carcinomas over the period from 2003 to 2015,16 with lymph node metastasis on surgical specimens were excluded from the present study. Further exclusions included 23 patients lost to follow-up; the proportion of patients lost was similar between the stage 0 and 1 groups $(5.0 \%$ and $4.7 \%$, respectively, $p=.9)$. Thus, the final study comprised 450 patients, i.e., 268 with stage 0 and 182 with stage 1 CRCs. Among the 63 gastroenterologists involved between 2003 and 2015, 14 performed at least 15 colonoscopies harboring one early-stage CRC. The characteristics of the patients, tumours and follow-up for the entire cohort and for the two groups separately are given in Table 1 . The mean duration of follow-up was 6.6 years. The cancer recurred for 9 patients, 5 times in the form of distant metastases and all in stage 1 , and there were 4 cancer-related deaths. The remaining four cases corresponded to local recurrences detected at colonoscopy.

Imaging surveillance

The detailed follow-up for the entire cohort and stage 0 and 1 groups is given in Table 2, and comparisons between groups according to the occurrence of imaging surveillance are given in Table 3. At least one imaging procedure was performed for 159 (35.3\%) patients, and 96 (60.4\%) underwent imaging surveillance that was qualified as intensive. As expected, imaging surveillance was significantly more frequent for stage 1 than in stage 0 patients (66.5 vs $14.2 \%$, $\mathrm{p}<.0001$ ), as was intensive monitoring (Table 2). The median number of imaging procedures performed for patients undergoing surveillance was 5 and 2 for US and CT, respectively, across the entire cohort and did not differ significantly between the stage 0 and 1 groups. The 
proportion of patients who had more than one examination (US or CT scan) among those defined as receiving imaging surveillance was $86.2 \%, 89.5 \%$ and $85.1 \%$ for the stage 0 and 1 groups, respectively.

Within the stage 1 group, 17 of the 47 patients (36.2\%) treated by endoscopic or transanal resection alone were followed up by imaging monitoring, including 10 of 36 patients (27.8\%) at low risk and 7 of 11 patients (63.6\%) at high risk of lymph node metastasis $(p=.07)$. Among the 135 patients treated by surgical resection, the proportion who underwent imaging surveillance was similar between the low- and high-risk groups ( 77.5 vs $76.6 \%, p=.90$ ) (Table 4).

Among the 5 patients with distant metastasis, one was a patient with a high-risk tumour resected by endoscopy alone, while the other 4 were treated by primary surgical resection. Imaging surveillance led to a diagnosis of liver metastasis for one patient; two cases of liver and peritoneal metastases were diagnosed through a 18-FDG PET-scan due to elevated serum carcinoembryonic antigen levels following negative CT scans; the other 2 cases of bone metastases were diagnosed with symptoms that appeared in patients who had been monitored by US.

Factors associated with imaging surveillance

\section{The entire cohort}

Univariable and multivariable logistic regression identified the following factors significantly associated with imaging surveillance: surgical vs endoscopic resection (OR=16.8 [8.2; 34.2]; $\mathrm{p}<.001$ ), cancer staging (stage 1 vs $0, \mathrm{OR}=8.3[4.3 ; 15.9] ; \mathrm{p}<.0001$ ) and the gastroenterologist in charge of the patient $(p<.0001)$ (Table 5). Similar results were obtained after moving patients treated by transanal resection from the surgery group to the endoscopic treatment 
group (data not shown; results available upon requests). Tumour location and tumour size greater than $30 \mathrm{~mm}$ were significantly associated with imaging surveillance by univariable analysis but not by multivariable analysis. After excluding cancer staging from the multivariable analysis, the two factors found to be significantly associated with imaging surveillance were surgical vs endoscopic resection (OR=33.7 [17.4; 65.2]; $p<.0001)$ and the gastroenterologist in charge of the patient $(p<.0001)$. The same two factors were also found to be significantly associated with intensive monitoring (data not shown).

\section{Stage 0 group}

The two factors significantly associated with imaging surveillance by multivariable analysis were tumour size $(\geq 30 \mathrm{~mm}, \mathrm{OR}=8.5[3.1 ; 23.4] ; \mathrm{p}<.0001)$ and the gastroenterologist in charge of the patient $(p=.0058)$. Surgical vs endoscopic resection and tumour location were associated with imaging surveillance by univariable analysis $(O R=8.2, p<.0001$ and $O R=5.5$, $p=.0008$, for tumours in the proximal colon) but not by multivariable analysis.

\section{Stage 1 group}

The factors significantly associated with imaging surveillance by multivariable analysis were surgical vs endoscopic resection $(\mathrm{OR}=8.4[3.8 ; 18.6] ; \mathrm{p}<.0001)$ and patient management prior to 2009 (OR=2.4 [1.2; 4.8]; $p=.019)$. A histologically high risk of lymph node metastasis, which was found at the limit of significance by univariable analysis (OR=1.90 [0.99; 3.6], $p=.058$ ), was not associated with imaging surveillance by multivariable analysis. When moving patients treated by transanal resection from the surgery group to the endoscopic treatment group, surgical resection vs local resection remained significantly associated with imaging surveillance $(\mathrm{OR}=5.8[2.8 ; 12.1] ; \mathrm{p}<.0001)$, as did management prior to $2009(\mathrm{OR}=2.2[1.1 ; 4.4]$; $\mathrm{p}=.027)$. 


\section{Discussion}

We are not aware of any publication in the literature on imaging surveillance of screeningdetected early-stage CRCs. In the present study, early-stage CRCs were restricted to intramucosal carcinomas, also called Tis, (stage 0) and to T1NO (stage 1) carcinomas [15]. T2N0 carcinomas that are also stage I tumours were not included in this study [15]. This longitudinal cohort study showed that imaging surveillance defined by the realization of at least one US or CT examination after curative resection of CRC involved $35.3 \%$ of the patients with early-stage CRC and was more frequently performed for those with stage 1 (65.5\%) than stage 0 cancer (14.2\%). The corresponding values for intensive surveillance were $40.7 \%$ and $8.2 \%$, respectively. Whereas major differences in follow-up practices for patients with CRC have been previously reported for more advanced tumours [18], there are no reported data for early-stage cancers. Multivariable analysis of the entire cohort identified 3 factors associated with imaging surveillance in this study, i.e., the cancer stage, the gastroenterologist in charge of the initial diagnosis and management and surgical vs endoscopic resection of the malignant polyp. After excluding cancer stage from the multivariable analysis, the remaining factors were still significantly associated with imaging surveillance, and the mean odds ratio for surgical vs endoscopic resection increased from 16.8 to 33.7. When moving patients treated by transanal resection from the surgery group to the endoscopic treatment group, similar findings were observed. It may appear paradoxical that the majority $(82.4 \%)$ of patients treated surgically without any sign of lymph node invasion on surgical specimens were more often monitored by imaging than those treated by endoscopic resection alone (17.6\%). We hypothesize that patients undergoing surgery were considered more serious, particularly by the 
gastroenterologist in charge of the patient, who also emerged as a factor significantly associated with imaging surveillance for the entire cohort and for the stage 0 group.

The fact that surgical resection did not emerge as a factor significantly associated with imaging surveillance in the latter group is probably due to the small number of patients in this group who were surgically treated and to the strong link previously demonstrated between the gastroenterologist and surgical treatment [14]. Although only $14.2 \%$ of patients in the stage 0 group were followed up with imaging, those who were followed up underwent the same number of examinations as stage 1 patients. This is still excessive monitoring, resulting in unjustified additional costs to the screening programme and potentially impacting the patients psychologically. As expected, no cases of distant metastasis occurred in this stage 0 group. Some authors are opposed to the term "cancer" to designate stage 0 tumours because in their opinion, it could lead to unnecessary surgery [19]. Even though we have not observed this in our experience [14], we cannot rule out the fact that this may have prompted some practitioners to conduct unnecessary imaging surveillance.

In the stage 1 group, the rate of imaging surveillance was found to be as high as $66.5 \%$. The two factors identified as being associated with imaging surveillance in that group by multivariable analysis were surgical vs endoscopic resection and initial management prior to 2009. a) The rate of imaging surveillance was 2.1 times higher among patients who had undergone surgical resection $(77.0 \%)$ than those treated by local (endoscopic or surgical transanal) resection alone (36.2\%). Similar differences were extracted from a small series of T1NO CRCs from the Netherlands, where abdominal and thoracic imaging follow-up rates were $18.2 \%$ and $9.1 \%$ in patients with locally resected tumours versus $36.4 \%$ and $36.4 \%$ in those surgically treated [20]. With respect to European recommendations regarding screeningdetected T1 tumours, only those with at-risk tumours not surgically resected should have been 
monitored by imaging [5]. A recent survey revealed enormous variation of practice among Dutch physicians surveyed online for follow-up strategies for locally resected high-risk T1 carcinomas [21]. In our study, the imaging monitoring rate was $63.6 \%$ for the small group of patients with locally resected high-risk T1 carcinomas. Moreover, the histologic risk of lymph node metastasis was not a factor associated with imaging surveillance for the entire group of stage 1 patients, so that among patients treated surgically, the proportion who underwent imaging surveillance was quite similar between patients with low- and high-risk tumours. However, among those whose tumor had been locally resected, imaging surveillance was logically more frequent for high-risk tumors (63.6\%) than for low-risk tumors (27.8\%). There exists no literature on the benefit of sequential imaging over time. Two recent meta-analyses showed that the cumulative incidence of distal cancer recurrence was 3.5\% and $5.5 \%$ after the endoscopic resection of high-risk T1 carcinomas $[22,23]$. The present study demonstrates the poor performance of monitoring, with only one case of metastasis detected and four missed diagnoses among the 121 patients with T1 cancers followed up by imaging. Indeed, the ratio between the number of distant metastases detected and the number of imaging procedures performed is completely unacceptable in terms of both additional cost and potential risk. b) After 2009, the use of imaging surveillance became significantly less frequent (48.5\%) than before 2009 (71.5\%). This date did not correspond to the publication of new guidelines in France but probably to an awareness among gastroenterologists that the current guidelines were outdated. However, it was not until 2019 that the guidelines were updated; they now recommend imaging surveillance only for stages 2 and 3 but not stage 1 CRCs, implying that locally resected high-risk T1 cancers should be treated with complementary surgery [16]. Nevertheless, some authors continue to believe that patients with high-risk T1 CRC should be offered personalized surveillance through shared decision-making while also taking into 
account the physical status and life expectancy of the patient [23]. For this reason, the issue of imaging surveillance should be discussed in multidisciplinary tumor meetings, which was not the case in this study, where only one third of the patient charts were presented to discuss only therapeutic management.

The main limitation of the study is the retrospective nature of the follow-up data, while the cohort was created prospectively. However, few patients were lost to follow-up, and the records of the remaining patients were manually reviewed. Strengths also included the completeness of CRC cases detected by the fecal test screening programme over the designated time period and the long duration of follow-up.

In conclusion and based on the most recent guidelines, this study demonstrated excessive imaging monitoring for early-stage CRCs, with 2 associated factors, i.e., the gastroenterologist in charge of the patient and surgical vs endoscopic resection of the tumour. These findings reinforce the opinion that malignant polyps should be preferentially resected by endoscopy whenever possible, which implies referring patients to expert endoscopists as much as possible. This study also questions the accuracy and appropriateness of current recommendations. The new French recommendations excluding stage 1 cancers from imaging surveillance have the advantage of simplifying the message for practitioners.

\section{Conflict of interest}

The authors declare no conflict of interest. 


\section{CLINRE-D-21-0036}

Data statement

The authors state that the data from their study is available on request.

Authors' contributions: conception and design (JFB, CP, MC, $A L$ ); analysis and interpretation of the data (MB, CR, TG, JFB, AL); drafting of the article (MB, JFB, AL). All of the authors approved the final manuscript.

\section{Funding}

None

\section{ACKNOWLEDGEMENTS}

The authors acknowledge the contributions of the general practitioners, gastroenterologists and surgeons in the district of Ille-et-Vilaine. They also acknowledge the staff in charge of the database at the screening centre, particularly Samuel Foucrit, a computer scientist. 


\section{References}

1. Levin TR, Corley DA, Jensen CD, et al. Effects of Organized Colorectal Cancer Screening on Cancer Incidence and Mortality in a Large Community-Based Population. Gastroenterology 2018;155:1383-91.e5.

2. Siegel RL, Miller KD, Goding Sauer A, et al. Colorectal cancer statistics, 2020. CA Cancer J Clin 2020;70:145-64.

3. Ferlay J, Colombet M, Soerjomataram I, et al. Cancer incidence and mortality patterns in Europe: Estimates for 40 countries and 25 major cancers in 2018. Eur J Cancer 2018;103:356-87.

4. Steele RJC. Overview of colorectal cancer screening. Colorectal Dis 2019;21 Suppl 1:14-5.

5. Steele R, Pox C, Kuipers E, et al. European guidelines for quality assurance in colorectal cancer screening and diagnosis. First Edition - Management of lesions detected in colorectal cancer screening. Endoscopy 2012;44:SE140-50.

6. Liu SL, Cheung WY. Role of surveillance imaging and endoscopy in colorectal cancer followup: Quality over quantity? World J Gastroenterol 2019;25:59-68.

7. Meyerhardt JA, Mangu PB, Flynn PJ, et al. Follow-up care, surveillance protocol, and secondary prevention measures for survivors of colorectal cancer: American Society of Clinical Oncology clinical practice guideline endorsement. J Clin Oncol 2013;31:44654470 .

8. Benson AB, Venook AP, Al-Hawary MM, et al. NCCN Guidelines Insights: Colon Cancer, Version 2.2018. J Natl Compr Canc Netw 2018;16:359-69.

9. Labianca R, Nordlinger B, Beretta GD, et al. Early colon cancer: ESMO Clinical Practice Guidelines for diagnosis, treatment and follow-up. Annals of Oncology 2013;24:vi64-72.

10. Glimelius B, Tiret E, Cervantes A, et al. Rectal cancer: ESMO Clinical Practice Guidelines for diagnosis, treatment and follow-up. Ann Oncol 2013;24 Suppl 6:vi81-8.

11. Faivre J, Adenis A, Bretagne JF, et al. [Consensus conference. Prevention, diagnosis and treatment of colon cancer]. 1998:14.

12. Haute Autorité de Santé. [Colorectal cancer: screening and prevention methods in high and very high risk subjects]. 2008. Available at: https://www.hassante.fr/upload/docs/application/pdf/guide_colon_version_web.pdf [Accessed February 7, 2021].

13. Grainville T, Bretagne J-F, Piette $C$, et al. Management of T1 colorectal cancers detected at screening colonoscopy: A study from the French national screening programmeme. Dig Liver Dis 2020;52:909-17. 
14. Bordet M, Bretagne J-F, Piette $C$, et al. Reappraisal of the characteristics, management, and prognosis of intramucosal colorectal cancers and their comparison with T1 carcinomas. Gastrointest Endosc 2021;93:477-85.

15. Brierley JD, Gospodarowicz MK, Witterkind C, et al. The TNM classification of malignant tumours. 8th edition. New York: Wiley; 2017.

16. Lecomte $T$, André $T$, Bibeau $F$, et al. [Nonmetastatic colon cancer]. Thésaurus National de Cancérologie Digestive; 2019. Available at: https://www.snfge.org/tncd et http://www.tncd.org .

17. Quirke $\mathrm{P}$, Risio $\mathrm{M}$, Lambert $\mathrm{R}$, et al. Quality assurance in pathology in colorectal cancer screening and diagnosis-European recommendations. Virchows Arch 2011;458:1-19.

18. Qaderi SM, Wijffels NAT, Bremers AJA, et al. Major differences in follow-up practice of patients with colorectal cancer; results of a national survey in the Netherlands. BMC Cancer 2020;20:22.

19. Shaukat A, Kaltenbach T, Dominitz JA, et al. Endoscopic Recognition and Management Strategies for Malignant Colorectal Polyps: Recommendations of the US Multi-Society Task Force on Colorectal Cancer. Gastrointest Endosc 2020;92:997-1015.e1.

20. Dang H, Vos Tot Nederveen Cappel WH de, Zwaan SMS van der, et al. Quality of life and fear of cancer recurrence in T1 colorectal cancer patients treated with endoscopic or surgical tumour resection. Gastrointest Endosc 2019;89:533-544.

21. Gijsbers K, Graaf W de, Moons LMG, et al. High practice variation in risk stratification, baseline oncological staging, and follow-up strategies for T1 colorectal cancers in the Netherlands. Endosc Int Open 2020;8:E1117-22.

22. Antonelli G, Vanella G, Orlando D, et al. Recurrence and cancer-specific mortality after endoscopic resection of low- and high-risk pT1 colorectal cancers: a meta-analysis. Gastrointest Endosc 2019;90:559-69.e3.

23. Dang H, Dekkers N, le Cessie S, et al. Risk and Time Pattern of Recurrences After Local Endoscopic Resection of T1 Colorectal Cancer: A Meta-Analysis. Clin Gastroenterol Hepatol 2020 Dec 1;S1542-3565(20)31622-0. doi: 10.1016/j.cgh.2020.11.032. Online ahead of print. 
TABLE 1. Characteristics of patients and tumours and details of follow-up for the entire cohort of early-stage colorectal cancers and for both stage 0 and stage 1 groups

\begin{tabular}{|c|c|c|c|c|}
\hline & $\begin{array}{l}\text { Entire cohort } \\
(n=450)\end{array}$ & $\begin{array}{l}\text { Stage } 0 \text { group } \\
(n=268)\end{array}$ & $\begin{array}{l}\text { Stage } 1 \text { group } \\
(n=182)\end{array}$ & $P$ value \\
\hline Age (years) & $64.0 \pm 7.0$ & $63.8 \pm 7.1$ & $64.4 \pm 6.8$ & .3983 \\
\hline $\begin{array}{l}\text { Sex } \\
\text { Male } \\
\text { Female }\end{array}$ & $\begin{array}{l}288(64.0 \%) \\
162(36.0 \%)\end{array}$ & $\begin{array}{l}169(63.1 \%) \\
99(36.9 \%)\end{array}$ & $\begin{array}{l}119(65.4 \%) \\
63(34.6 \%)\end{array}$ & .614 \\
\hline $\begin{array}{l}\text { Ultimate cancer } \\
\text { treatment } \\
\text { Endoscopic resection } \\
\text { Surgical resection } \\
\text { (including transanal } \\
\text { resection) }\end{array}$ & $\begin{array}{l}254(56.4 \%) \\
196(43.6 \%) \\
(11)\end{array}$ & $\begin{array}{l}213(79.5 \%) \\
55(20.5 \%) \\
(5)\end{array}$ & $\begin{array}{l}41(22.5 \%) \\
141(77.5 \%) \\
(6)\end{array}$ & $<.0001$ \\
\hline $\begin{array}{l}\text { Tumour location } \\
\text { Proximal colon } \\
\text { Distal colon } \\
\text { Rectum }\end{array}$ & $\begin{array}{l}44(9.8 \%) \\
310(68.9 \%) \\
96(21.3 \%)\end{array}$ & $\begin{array}{l}28(10.4 \%) \\
185(69.0 \%) \\
55(20.5 \%)\end{array}$ & $\begin{array}{l}16(8.8 \%) \\
125(68.7 \%) \\
41(22.5 \%)\end{array}$ & .774 \\
\hline $\begin{array}{l}\text { Tumour size } \\
<20 \mathrm{~mm} \\
20-29 \mathrm{~mm} \\
\geq 30 \mathrm{~mm}\end{array}$ & $\begin{array}{l}173(38.4 \%) \\
167(37.1 \%) \\
110(24.4 \%)\end{array}$ & $\begin{array}{l}106(39.6 \%) \\
92(34.3 \%) \\
70(26.1 \%)\end{array}$ & $\begin{array}{l}67(36.8 \%) \\
75(41.2 \%) \\
40(22.0 \%)\end{array}$ & .308 \\
\hline $\begin{array}{l}\text { Duration of follow-up } \\
\text { (years) }\end{array}$ & $6.60 \pm 3.86$ & $6.06 \pm 3.76$ & $7.38 \pm 3.87$ & .0003 \\
\hline $\begin{array}{l}\text { Cancer recurrence } \\
\text { Yes } \\
\text { No }\end{array}$ & $\begin{array}{l}9(2.0 \%) \\
441(98.0 \%)\end{array}$ & $\begin{array}{l}0(0.0 \%) \\
268(100.0 \%)\end{array}$ & $\begin{array}{l}9(4.9 \%) \\
173(95.1 \%)\end{array}$ & .0003 \\
\hline $\begin{array}{l}\text { Death } \\
\text { Yes } \\
\text { No }\end{array}$ & $\begin{array}{l}45(10.0 \%) \\
405(90.0 \%)\end{array}$ & $\begin{array}{l}14(5.2 \%) \\
254(94.8 \%)\end{array}$ & $\begin{array}{l}31(17.0 \%) \\
151(83.0 \%)\end{array}$ & .0001 \\
\hline $\begin{array}{l}\text { Cancer-related death } \\
\text { Yes } \\
\text { No }\end{array}$ & $\begin{array}{l}4(0.9 \%) \\
446(99.1 \%)\end{array}$ & $\begin{array}{l}0(0.0 \%) \\
268(100.0 \%)\end{array}$ & $\begin{array}{l}4(2.2 \%) \\
178(97.8 \%)\end{array}$ & .0262 \\
\hline
\end{tabular}


TABLE 2. Details of imaging surveillance for the entire cohort of early-stage colorectal cancers and for both stage 0 and stage 1 groups

\begin{tabular}{|c|c|c|c|c|}
\hline & $\begin{array}{l}\text { Entire cohort } \\
(n=450)\end{array}$ & $\begin{array}{l}\text { Stage } 0 \text { group } \\
(n=268)\end{array}$ & $\begin{array}{l}\text { Stage } 1 \text { group } \\
(n=182)\end{array}$ & $P$ value \\
\hline $\begin{array}{l}\text { Imaging surveillance } \\
\text { Yes } \\
\text { No }\end{array}$ & $\begin{array}{l}159(35.3 \%) \\
291(64.7 \%)\end{array}$ & $\begin{array}{l}38(14.2 \%) \\
230(85.8 \%)\end{array}$ & $\begin{array}{l}121(66.5 \%) \\
61(33.5 \%)\end{array}$ & .0001 \\
\hline $\begin{array}{l}\text { Intensive imaging } \\
\text { surveillance } \\
\text { Yes } \\
\text { No }\end{array}$ & $\begin{array}{l}96(21.3 \%) \\
354(78.7 \%)\end{array}$ & $\begin{array}{l}22(8.2 \%) \\
246(91.8 \%)\end{array}$ & $\begin{array}{l}74(40.7 \%) \\
108(59.3 \%)\end{array}$ & .0001 \\
\hline \multicolumn{5}{|l|}{ Ultrasonographic surveillance } \\
\hline $\begin{array}{l}\text { At least one examination } \\
\text { Yes } \\
\text { No }\end{array}$ & $\begin{array}{l}149(33.1 \%) \\
301(66.9 \%)\end{array}$ & $\begin{array}{l}37(13.8 \%) \\
231(86.2 \%)\end{array}$ & $\begin{array}{l}112(61.5 \%) \\
70(38.5 \%)\end{array}$ & .0001 \\
\hline $\begin{array}{l}\text { Median number of } \\
\text { examinations (when at least } \\
\text { one examination was } \\
\text { performed) [interquartile } \\
\text { range] }\end{array}$ & $5.0[2.0 ; 10.0]$ & $5.0[2.0 ; 9.0]$ & $5.5[2.0 ; 10.0]$ & .505 \\
\hline \multicolumn{5}{|c|}{ Computed tomography surveillance } \\
\hline $\begin{array}{l}\text { At least one examination } \\
\text { Yes } \\
\text { No }\end{array}$ & $\begin{array}{l}55(12.2 \%) \\
395(87.8 \%)\end{array}$ & $\begin{array}{l}6(2.2 \%) \\
262(97.8 \%)\end{array}$ & $\begin{array}{l}49(26.9 \%) \\
133(73.1 \%)\end{array}$ & .0001 \\
\hline $\begin{array}{l}\text { Median number of } \\
\text { examinations (when at least } \\
\text { one examination was } \\
\text { performed) [interquartile } \\
\text { range] }\end{array}$ & $2.0[1.0 ; 3.0]$ & $2.5[1.0 ; 3.0]$ & $2.0[1.0 ; 3.0]$ & .790 \\
\hline
\end{tabular}


CLINRE-D-21-0036

TABLE 3. Comparison of the occurrence of imaging follow-up for the entire cohort and for the stage 0 and stage 1 groups

\begin{tabular}{|c|c|c|c|c|c|c|c|c|c|}
\hline & \multicolumn{3}{|l|}{ Entire cohort } & \multicolumn{3}{|l|}{ Stage 0} & \multicolumn{3}{|l|}{ Stage I } \\
\hline & \multicolumn{2}{|c|}{ Imaging surveillance } & \multirow[b]{2}{*}{$P$ value } & \multicolumn{2}{|c|}{ Imaging surveillance } & \multirow[b]{2}{*}{ P value } & \multicolumn{2}{|c|}{ Imaging surveillance } & \multirow[b]{2}{*}{ P value } \\
\hline & Yes $(n=159)$ & No $(N=291)$ & & Yes $(n=38)$ & No $(n=230)$ & & Yes $(n=121)$ & No $(n=61)$ & \\
\hline Mean age, years (SD) & $64.2(7.0)$ & $63.9(7.0)$ & .70 & $62.2(7.0)$ & $64.1(7.1)$ & .13 & $64.8(6.9)$ & $63.4(6.7)$ & .20 \\
\hline $\begin{array}{lr}\text { Sex } & \begin{array}{r}\text { male } \\
\text { female }\end{array}\end{array}$ & $\begin{array}{l}107(67.3 \%) \\
52(32.7 \%)\end{array}$ & $\begin{array}{l}181(62.2 \%) \\
110(37.8 \%)\end{array}$ & .28 & $\begin{array}{l}25(65.8 \%) \\
13(34.2 \%)\end{array}$ & $\begin{array}{l}144(62.6 \%) \\
86(37.4 \%)\end{array}$ & .71 & $\begin{array}{l}82(67.8 \%) \\
39(32.2 \%)\end{array}$ & $\begin{array}{l}37(60.7 \%) \\
24(39.3 \%)\end{array}$ & .34 \\
\hline $\begin{array}{l}\text { Cancer treatment } \\
\text { Endoscopic resection } \\
\text { Surgical resection }\end{array}$ & $\begin{array}{l}28(17.6 \%) \\
131(82.4 \%) \\
\end{array}$ & $\begin{array}{l}226(77.7 \%) \\
65(22.3 \%) \\
\end{array}$ & $<.0001$ & $\begin{array}{l}16(42.1 \%) \\
22(57.9 \%) \\
\end{array}$ & $\begin{array}{l}197(85.7 \%) \\
33(14.3 \%)\end{array}$ & .0001 & $\begin{array}{l}12(9.9 \%) \\
109(90.1 \%)\end{array}$ & $\begin{array}{l}29(47.5 \%) \\
32(52.5 \%)\end{array}$ & .0001 \\
\hline $\begin{array}{l}\text { Tumour location } \\
\text { Proximal colon } \\
\text { Distal colon } \\
\text { Rectum }\end{array}$ & $\begin{array}{l}23(14.5 \%) \\
97(61.0 \%) \\
39(24.5 \%)\end{array}$ & $\begin{array}{l}21(7.2 \%) \\
213(73.2 \%) \\
57(19.6 \%)\end{array}$ & .012 & $\begin{array}{l}10(26.3 \%) \\
17(44.7 \%) \\
11(28.9 \%)\end{array}$ & $\begin{array}{l}18(7.8 \%) \\
168(73.0 \%) \\
44(19.1 \%)\end{array}$ & .0007 & $\begin{array}{l}13(10.7 \%) \\
80(66.1 \%) \\
28(23.1 \%)\end{array}$ & $\begin{array}{l}3(4.9 \%) \\
45(73.8 \%) \\
13(21.3 \%)\end{array}$ & .373 \\
\hline $\begin{array}{l}\text { Tumour size } \\
<20 \mathrm{~mm} \\
20-29 \mathrm{~mm} \\
\geq 30 \mathrm{~mm}\end{array}$ & $\begin{array}{l}45(28.3 \%) \\
59(37.1 \%) \\
55(34.6 \%)\end{array}$ & $\begin{array}{l}128(44.0 \%) \\
108(37.1 \%) \\
55(18.9 \%)\end{array}$ & .0002 & $\begin{array}{l}7(18.4 \%) \\
8(21.1 \%) \\
23(60.5 \%)\end{array}$ & $\begin{array}{l}99(43.0 \%) \\
84(36.5 \%) \\
47(20.4 \%)\end{array}$ & .0001 & $\begin{array}{l}38(31.4 \%) \\
51(42.1 \%) \\
32(26.4 \%)\end{array}$ & $\begin{array}{l}29(47.5 \%) \\
24(39.3 \%) \\
8(13.1 \%)\end{array}$ & .044 \\
\hline $\begin{array}{l}\text { Risk of lymph node } \\
\text { metastasis* } \\
\text { low } \\
\text { high }\end{array}$ & & W & & & & & $\begin{array}{l}65(53.7 \%) \\
56(46.3 \%)\end{array}$ & $\begin{array}{l}42(68.9 \%) \\
19(31.1 \%)\end{array}$ & .0505 \\
\hline $\begin{array}{l}\text { Difference according } \\
\text { to the endoscopist }\end{array}$ & 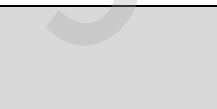 & & .0001 & & & .0001 & & & .009 \\
\hline
\end{tabular}




\section{CLINRE-D-21-0036}

\begin{tabular}{|c|c|c|c|c|c|c|c|c|c|}
\hline $\begin{array}{l}\text { Year of initial } \\
\text { management } \\
2009 \text { or before } \\
\text { After } 2009\end{array}$ & $\begin{array}{l}114(36.5 \%) \\
45(32.6 \%)\end{array}$ & $\begin{array}{l}198(63.5 \%) \\
93(67.4 \%)\end{array}$ & .421 & $\begin{array}{l}26(13.6 \%) \\
12(15.6 \%)\end{array}$ & $\begin{array}{l}165(86.4 \%) \\
65(84.4 \%)\end{array}$ & .675 & $\begin{array}{l}88 \text { (71.5\%) } \\
33(48.5 \%)\end{array}$ & $\begin{array}{l}33(26.8 \%) \\
28(41.2 \%)\end{array}$ & .012 \\
\hline UICC stage & & & $<.0001$ & & & & & & \\
\hline Stage 0 & 38 (23.9\%) & 230 (79.0\%) & & & & & & & \\
\hline Stage I & 121 (76.1\%) & 61 (21.0\%) & & & & & & & \\
\hline
\end{tabular}

* Patients were categorized as having either a low or high risk of lymph node metastasis according to the absence or presence of at least one of the following prognostic pathological criteria: poor differentiation, venous and lymphatic invasion, tumour budding, submucosal invasion depth $\geq 1000 \mu m$ for sessile polyps or a Haggitt level of invasion $\geq 3$ for pedunculated polyps, and margin involvement with a clearance of $1 \mathrm{~mm}$ or less [17] 


\section{CLINRE-D-21-0036}

TABLE 4. Distribution of imaging surveillance for stage 1 patients according to final treatment and histologic risk of lymph node metastasis

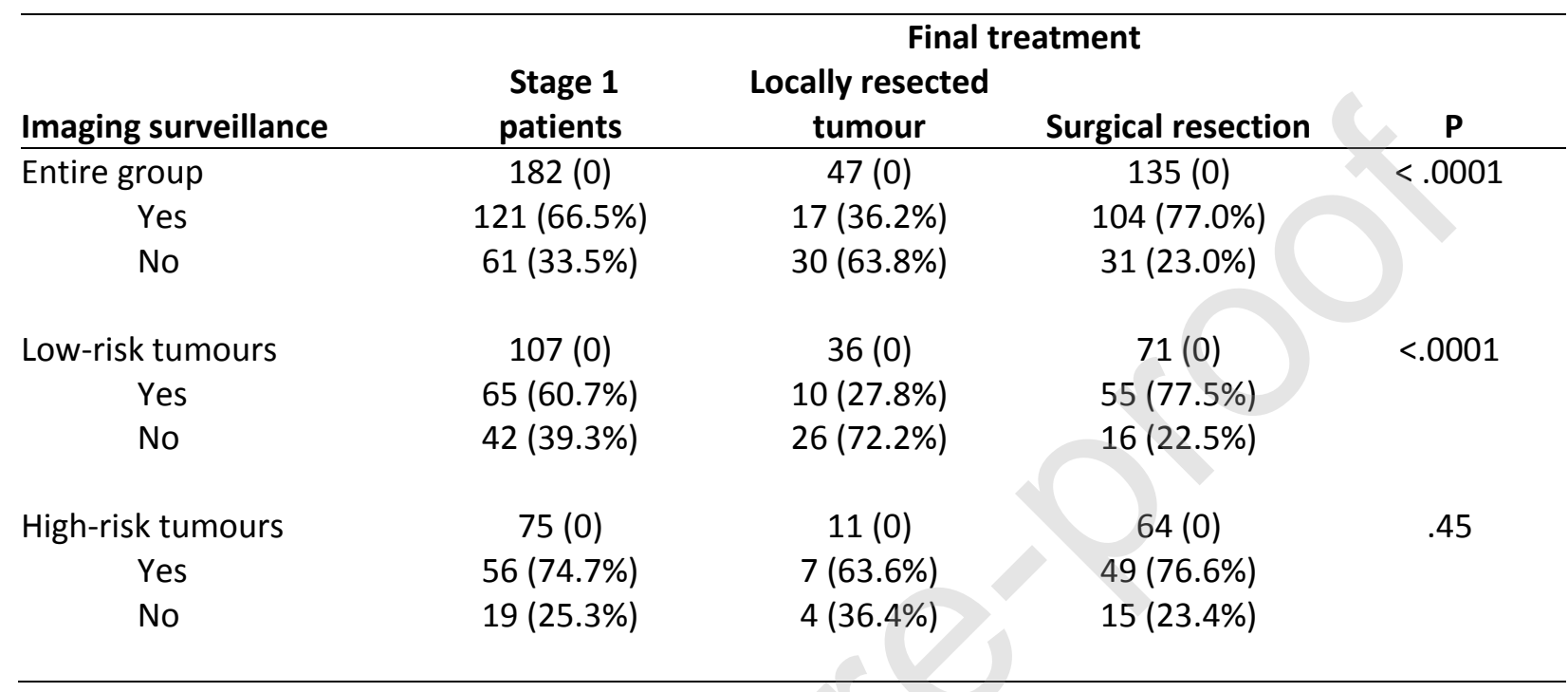


TABLE 5 Factors significantly associated with imaging monitoring for the entire cohort of early-stage colorectal cancers $(n=450)$ by univariable or multivariable logistic regression analysis

\begin{tabular}{|c|c|c|c|c|c|c|}
\hline \multirow[t]{2}{*}{ Variable } & \multicolumn{3}{|c|}{ Univariable analysis } & \multicolumn{3}{|c|}{ Multivariable analysis } \\
\hline & OR & $95 \% \mathrm{Cl}$ & $P$ value & OR & $95 \% \mathrm{Cl}$ & $P$ value \\
\hline \multicolumn{7}{|c|}{ Cancer treatment } \\
\hline $\begin{array}{l}\text { Endoscopic } \\
\text { resection }\end{array}$ & 1 (ref) & & .0001 & 1 (ref) & & .0001 \\
\hline $\begin{array}{l}\text { Surgical } \\
\text { resection }\end{array}$ & 16.27 & {$[9.9 ; 26.6]$} & & 16.81 & {$[8.3 ; 34.2]$} & \\
\hline \multicolumn{7}{|c|}{ Tumour location } \\
\hline Distal & 1 (ref) & & .0130 & & & \\
\hline Proximal & 2.40 & {$[1.3 ; 4.5]$} & & & & \\
\hline Rectum & 1.50 & {$[0.94 ; 2.4]$} & & & & \\
\hline \multicolumn{7}{|l|}{ Tumour size } \\
\hline$<20 \mathrm{~mm}$ & 1 (ref) & & .0003 & & & \\
\hline $20-29 \mathrm{~mm}$ & 1.55 & {$[0.98 ; 2.5]$} & & & & \\
\hline$\geq 30 \mathrm{~mm}$ & 2.84 & {$[1.7 ; 4.7]$} & & & & \\
\hline \multicolumn{7}{|l|}{ Cancer staging } \\
\hline Stage 0 & 1 (ref) & 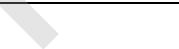 & $<.0001$ & 1 (ref) & & .0001 \\
\hline Stage 1 & 12.00 & {$[7.6 ; 19.0$} & & 8.33 & {$[4.4 ; 15.9]$} & \\
\hline \multicolumn{7}{|c|}{ Year of initial management } \\
\hline 2009 or prior & 1 (ref) & & .4216 & & & \\
\hline After 2009 & 0.84 & {$[0.55 ; 1.3]$} & & & & \\
\hline 4 & 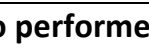 & 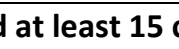 & pies & & & \\
\hline
\end{tabular}




\section{CLINRE-D-21-0036}

\begin{tabular}{|c|c|c|c|c|c|c|}
\hline$A$ & 1 (ref) & & .0040 & 1 (ref) & & .0001 \\
\hline$B$ & 1.00 & {$[0.29 ; 3.5]$} & & 3.66 & {$[0.61 ; 22.1]$} & \\
\hline $\mathrm{C}$ & 26.25 & {$[4.96 ; 138.9]$} & & 296.06 & {$[36.8 ; 2379.8]$} & \\
\hline $\mathrm{D}$ & 1.67 & {$[0.50 ; 5.6]$} & & 3.14 & {$[0.48 ; 20.4]$} & \\
\hline$E$ & 1.14 & {$[0.30 ; 4.3]$} & & 1.26 & {$[0.18 ; 8.8]$} & \\
\hline $\mathrm{F}$ & 3.06 & {$[0.92 ; 10.2]$} & & 8.69 & {$[1.58 ; 47.8]$} & \\
\hline G & 0.92 & {$[0.28 ; 3.0]$} & & 0.90 & {$[0.17 ; 4.8]$} & \\
\hline $\mathrm{H}$ & 0.63 & {$[0.14 ; 2.8]$} & & 0.30 & {$[0.05 ; 1.9]$} & \\
\hline $\mathrm{I}$ & 1.07 & {$[0.30 ; 3.8]$} & & 5.33 & {$[0.88 ; 32.1]$} & \\
\hline $\mathrm{J}$ & 0.83 & {$[0.24 ; 2.9]$} & & 3.32 & {$[0.53 ; 20.6]$} & \\
\hline $\mathrm{K}$ & 1.25 & {$[0.32 ; 4.8]$} & & 1.89 & {$[0.26 ; 13.9]$} & \\
\hline $\mathrm{L}$ & 0.34 & {$[0.08 ; 1.5]$} & & 0.75 & {$[0.10 ; 5.8]$} & \\
\hline$M$ & 2.75 & $[0.84 ; 9.0]]$ & & 4.23 & {$[0.76 ; 23.5]$} & \\
\hline $\mathrm{N}$ & 1.47 & {$[0.47 ; 4.6]$} & & 2.16 & {$[0.42 ; 11.3]$} & \\
\hline $\begin{array}{l}\text { The other } 49 \\
\text { endoscopists }\end{array}$ & 1.22 & {$[0.50 ; 3.0]$} & & 1.34 & {$[0.37 ; 4.9]$} & \\
\hline
\end{tabular}

